\title{
College English-major Teaching Based on Service-oriented Teaching Mode
}

\author{
Xiaogong Li, Jiali Yuan \\ School of Foreign Language, Hebei University of Science and Technology, Shijiazhuang Hebei, \\ 050000, China
}

Keywords: Service-oriented, Teaching mode, College, English major, Teaching

\begin{abstract}
In English-major teaching, colleges must change their teaching philosophy, to make English teaching in line with the world, so that students can quickly adapt to society during social contacts. Meanwhile, through learning students can meet social service-oriented translation requirements. However, at present college English-major teaching still has many problems, for example, English teaching objectives have not yet achieved and students' English practical ability remains to be improved. Because service-oriented teaching mode has a significant role for teaching, it should be widely used in college English teaching. Therefore, this paper focuses on analysis on service-oriented teaching mode and its role in college English-major teaching so as to provide favorable protection for comprehensively training English professionals.
\end{abstract}

\section{Introduction}

Since the 21st century, in order to promote rapid development of society, China strengthens the emphasis on education. At present, China has increasingly growing trade scale and trades frequently with other countries, so English, as the bridge of communication between countries, lays a good foundation for our economic globalization development. In college English teaching, cultivation of English professionals should be the main objective. Meanwhile, in order to adapt to the sound development of society, also integrate the concept of serving society throughout the teaching process. However, traditional English teaching mode enables students equipped with solid theoretical foundation, but weak social practice ability, which fails to play a huge role in comprehensively training the overall quality of English majors. Currently, service-oriented teaching mode has its advantages, able to integrate service-oriented teaching philosophy into English teaching, which has a significant effect on enhancing the quality of English teaching. Therefore, it is necessary to strengthen the service-oriented teaching mode in college English teaching, to ensure significant improvement of students' social practice ability.

\section{Overview of service-oriented teaching mode}

Service-oriented teaching mode originated in the United States, and it is a new learning concept. Compared with the traditional concept, it is reflective to some degree and meets the needs of society; therefore service-oriented teaching mode is widely used in education, and can make teaching system more perfect. College English-major teaching, undertakes the responsibility of training English professionals with comprehensive ability, so in order to improve students' English language skills and social practice ability, expand application of service-oriented teaching mode in English-major teaching, and obtain good results, and provide favorable conditions for the development of college English teaching. Throughout college English teaching, we will find that during training English professionals, colleges put more energy on enhancing accumulation of students' theoretical knowledge, and service-oriented teaching is still not perfect, however, in language teaching, teachers must strengthen students' English practice, and take more time in enhancing students' participation and experience in English. Service-oriented teaching mode precisely can help students understand English language rules and grammar system. Therefore, in English-major teaching, colleges should create a good language practice environment for students, and let students try to use the language, to ensure improvement of students’ English language proficiency through mutual exchange. In order to 
improve the quality of English teaching, colleges must optimize teaching mode, in classroom teaching, should build a service-oriented environment for students, so that students can get more English knowledge in the role of service-oriented teaching mode. At the same time, through practice, at the greatest extent, serve the society, and thus pave the way for the development of the country.

\section{Advantages of service-oriented teaching mode}

\section{Enhance students' innovative ability.}

In English teaching, colleges use service-oriented teaching mode, and allow students to participate in social practice, and thus exert advantages of service-oriented teaching mode, and carry out participatory service-oriented teaching practice, to make students' innovative ability significantly improved $^{[1]}$. For example, teachers create a good learning environment for students, which can help significantly improve students' innovative ability. The connotation of language is to convert intangible language into tangible language. In real environment, students can contact with people and things face to face, and then through innovation, they can present English language in the form of facial expressions and communication voice, so as to innovate the use of English language, to achieve the best result of learning English. At the same time, by the role of service-oriented teaching mode, and "voice narration" method, teachers can constantly develop students' English practical ability. Therefore, service-oriented teaching mode has some advantages in improving students' innovative ability.

\section{Enhance students' autonomy.}

Service-oriented teaching mode also has the advantage to enhance students' self-learning ability. At present, in training English professionals, colleges are more inclined to improve learning ability, make service-oriented teaching mode play a significant role through improvement of the enthusiasm of students to learn English. In service-oriented teaching mode, English teachers will create a good language situation or circumstance for students, to make students flexibility use English in the exchange, and then develop their independent learning ability, to enhance the interest of talkers in conversation. At the same time, students can get the information they want, which has a significant role in improvement of their comprehensive ability. In addition, before participating in English interactive practice, students themselves must gather relevant information and integrate information resources together. Through self-learning, they can enhance their English autonomous learning ability. Therefore, service-oriented learning mode has the advantage to enhance the students' autonomous ability, and has an important role in improvement of English teaching quality.

\section{Enhance students' awareness of service.}

The ultimate goal of English majors learning is to better serve the society, to use the English knowledge they have learnt, and then interact with foreign persons, for promoting national economic development. Therefore, application of service-oriented teaching mode in English-major teaching in colleges, allows students to experience the value of serving the society, and enhance the sense of cooperation of students at the same time. College English teaching objectives should not be confined to the theoretical knowledge teaching, but more necessary to arrange more English practice activities for students, to enable students to understand that learning English knowledge is largely for better serving the society, and learning excellent quality in other persons in practice, to make up their own shortcomings. Overall, application of service-oriented teaching mode in college English teaching is to enhance students' service awareness, then to promote national economic growth in the work.

\section{Current problems existing in college English-major teaching}

\section{Lack of language environment.}

Currently, in college English teaching, the lack of language environment leads to students fail to fully mobilize the enthusiasm and do not have a strong interest in English language during English learning. In traditional teaching mode, teachers just organize students to discuss English teaching content in the classroom or in their extracurricular time. However, this teaching mode has some drawbacks. Students can only reflect on the content and questions already set by teachers, and 
teachers arrange students to learn English with purpose, but not let students use English to communicate with improvisation in a specific language environment. Meanwhile, during English-major teaching, some colleges do not conduct thorough and deep research and investigation on activity content. Activity content is not really and organically connected with English language, resulting in English learning content is not in line with the needs of the society, and students' English practical ability in society is still lacking.

\section{Lack of sufficient awareness of service.}

Currently, in college English teaching, insufficient service awareness leads to students learn a wealth of English knowledge, but not use them in social service, which has a negative impact on the development of the country. Some colleges have not yet had a profound knowledge on service, so in teaching, English curriculum arrangement is unreasonable and English teaching and work is not connected closely, which leads to the overall development of students is limited, and practice adaptation is lacking ${ }^{[2]}$. At the same time, to a certain extent, the use of the English language has the service nature. Participation of students in practical activities, can contribute to the sound development of society. However, at present, in high school, English professionals training extremely lacks social practice service, which leads to some deviation in understanding the language and weak sense of service. Therefore, during their participation in social practice, students' service ability remains to be improved.

\section{Imperfect teaching mode.}

English is as a second language. In order to ensure students improve their interest in learning, colleges must optimize teaching mode, but the current teaching mode is imperfect, leading to English teaching level does not make great progress. In traditional teaching mode, teachers are dominators, while students are passive English knowledge learners. In this environment for a long time, students' enthusiasm of independent learning English will decline, and the improvement of students' English proficiency will be limited. Therefore, in English teaching, due to imperfect teaching mode, teachers fail to adequately create a favorable context environment for students, which leads to students do not fully grasp English content. Meanwhile, during teaching, teaching is not organically linked with English environment and cultural background, which is not conducive to stimulate students' motivation to learn English, resulting in college English teaching floats on the form and students' English practical ability is still lacking.

\section{College English-major teaching based on service-oriented teaching mode}

\section{Combine life and English teaching.}

In order to train more English professionals, and ensure that students to better serve the society in their work, colleges strengthens service-oriented teaching mode. College English teaching, does allow students not just to learn English theoretical knowledge and read English, but to a greater extent to flexibly use English. During English learning, students must build a bridge between Chinese and English; while in carrying out teaching activities, teachers should connect life with teaching content organically, so as to play the role of service-oriented teaching mode, and allow students to discover the intrinsic value of English. For example, in college English translation teaching, teachers can choose some classic films in life to let students translate. Teachers can let students translate the content in "The Titanic", Titanic Characters Jake Dawson A 20-year-old artist from Chippewa Falls, Wisconsin. Orphaned at the age of 15, he worked a variety of jobs. After a stint as a logger, he came to Santa Monica, California, where he drew portraits on the pier for 10 cents apiece. After correctly understanding the content, then properly express, so as to learn English knowledge in context ${ }^{[3]}$. At the same time, teachers can also allow students to translate English news, to improve students' English self-learning ability through integration of life and English teaching together.

\section{Use voice narration method.}

English teaching in high school can also use voice narration method, so as to mobilize students' language reserve to the greatest degree ${ }^{[4]}$. Voice narration method refers to that in the exchange process, students always pay attention to feeling and meaning the other's and their voices convey. So the communication platform for domestic students and foreign students built by colleges, allows 
students to broaden horizons. For example, students can target different cultures for mutual discussion, and during the conversation domestic students should observe the other's facial expressions, voices, etc., and then imitate, for the correct pronunciation. At the same time, by listening to the other's voice, students can determine their own language express is very correct during exchange. In addition, they can also develop their strain capacity.

\section{Increase practice opportunities for students.}

Under the background of economic globalization, English plays a huge role in international exchange, so the state has higher requirements for professionals. English teaching objective in high school is to make students integrate into actual English language environment, and under new teaching philosophy to ensure effective connection of society with professionals, to enhance students' sense of social practice. In order to enhance the service ability of students, during English teaching, colleges also need to increase practice opportunities for students, to make students adapt to the social environment as soon as possible. For example, colleges can cooperate with some foreign companies, and let students translate business documents, to make them experience the connotation of English culture ${ }^{[5]}$. Meanwhile, in the actual work master how to apply English knowledge they have learnt, and then serve the society on their jobs. Therefore, increase practice opportunities for students to lay a good foundation for students to meet the needs of society.

\section{Conclusions}

In English teaching, colleges need create a good language environment for students, to significantly improve students' language proficiency, and promote English professionals trained by colleges to meet the needs of society. However, in traditional teaching mode, students' language practice ability is poor, and their awareness of service is lacking. Therefore, in order to make English professionals in colleges contribute to national economic growth, colleges must increase the intensity of service-oriented teaching mode, through the role of this mode, optimize students' language environment, and let them participate in social practice, so as to help enhance their English literacy. Meanwhile, students can contribute to national development when entering the society.

\section{Acknowledgments}

This paper is in Hebei Province Social Science Fund Project. Project Name: Multi-modal and Multi-environment Service-oriented English Learning Research. Project Number: HB13YY018.

\section{References}

[1] Cao Shenghua. Research on service-oriented teaching in college English-major teaching. Journal of Taiyuan City Vocational and Technical College, 2013 (4): 129-130.

[2] Cai Liang. Research on service-oriented English learning in Chinese foreign languages teaching environment - based on exploration of college English-major practical teaching. Shanghai International Studies University, 2012.

[3] Nie Jing. On college English service-oriented learning practice. Journal of Changchun Institute of Education, 2015 (3): 105-106.

[4] Zhang Tengfei. Application of "service-oriented learning" concept in practice teaching of English majors in normal university - taking Xinjiang Normal University for example. Journal Hubei Correspondence University, 2015 (19): 163-164.

[5] Li Xiaohong, Zhang Huixiao, Mao Guichu, etc. Combination of service-oriented learning and college education - serving is to learn, and learning is to better serve. Modern Enterprise Education, 2014 (24): 123-123. . 